\title{
Decadal trends and causes of sedimentation in the Inner Mongolia reach of the upper Yellow River, China
}

\author{
Changxing Shi* \\ Key Laboratory of Water Cycle and Related Land Surface Processes, Institute of Geographic Sciences and Natural Resources Research, Chinese \\ Academy of Sciences, Beijing 100101, China
}

\begin{abstract}
:
Using hydrological and sediment data, this study investigated decadal trends in sediment erosion/deposition in the Inner Mongolia reach of the upper Yellow River. The calculated yearly sediment erosion/deposition show that the reach was dominated by aggradation, degradation, and aggradation successively in three periods with the years around 1961 and 1987 as break-points. By constructing relations between water discharge and sediment load, the contributions of key factors to the changes in sediment erosion/deposition in the reach were quantified. Results show that the sediment retention behind the main stem dams, the increase of natural runoff, and the decrease of sediment inputs from tributaries and upstream watershed were the main factors causing the transition from aggradation during 1955-1961 to degradation during 1962-1987. The reduction of natural runoff, the decrease of sediment retention behind dams, and the rise of sediment supply from tributaries were the key causes of the reversal from degradation in 1962-1987 to aggradation in 1988-2003. Water diversion has played an important role in the long-term aggradation of the Inner Mongolia reach. The main stem dams had functioned to alleviate siltation after 1961, but their effects on siltation reduction had been gradually diminishing since the 1990s. Copyright @ 2015 John Wiley \& Sons, Ltd.
\end{abstract}

KEY WORDS upper Yellow River; alluvial river; upstream control; sediment rating curve; channel aggradation

Received 19 January 2014; Accepted 24 June 2015

\section{INTRODUCTION}

Climate change and human activities drive the outputs of water (magnitude, frequency, and duration of runoff events) and sediment (volume, calibre, and frequency of sediment delivery) from catchments to fluctuate over time (Trimble, 1981; Knox, 1993; Kosmas et al., 1997; Arnell, 1999; Bichet et al., 1999; Xu, 2004; Walling, 2009; Macklin et al., 2010; Shi et al., 2010). Water and sediment outputs from the uplands of the catchments fluctuate with changes in climate (Ward et al., 2009; Korhonen and Kuusisto, 2010; Shi et al., 2013) on different temporal scales (Schumm and Lichty, 1965; Hay, 1994; Owens and Slaymaker, 1994; Zolitschka, 1998; Tucker and Slingerland, 1997; Clift, 2006). Changes in water and sediment inputs can also arise from a wide variety of human activities (Clark and Wilcock, 2000; Tornqvist, 2007; Wilkinson and McElroy, 2007). River systems have been modified significantly by human pressure in the Anthropocene (Meybeck, 2003; Syvitski and Kettner, 2011), and their adjustments to anthropogenic perturbations can last for a long time

*Correspondence to: Changxing Shi, Institute of Geographic Sciences and Natural Resources Research, Chinese Academy of Sciences, A11, Datun Road, Chaoyang District, Beijing, 100101, China.

E-mail: shicx@igsnrr.ac.cn
(Singer et al., 2013). Among the human modes of interference, dams have been an efficient tool in changing the water and sediment fluxes of rivers, which in turn have induced noticeable adjustments in downstream channels (Vörösmarty et al., 2003; Syvitski et al., 2005; Walling, 2006; Singer, 2007; Syvitski and Milliman, 2007; Schmidt and Wilcock, 2008; Singer, 2010). With the growth of human power and demand for energy, water can be practically used up and sediment flux can be terminated even in a river as large as the Yellow River in China in low-flow seasons of some years, let alone in many smaller rivers (Zhang and Shi, 2001; Xu, 2004).

Water and sediment inputs are regarded as upstream controls governing changes in the channel of a river reach (Mackin, 1948; Tornqvist, 2007). Variations in water and sediment inputs may lead to channel aggradation or degradation (Lane, 1955; Williams and Wolman, 1984; Clark and Wilcock, 2000; Brandt, 2000; Petts and Gurnell, 2005; Slater and Singer, 2013). Since the behaviour of fluvial systems is often complex and non-linear, the direction and magnitude of channel aggradation or degradation is usually difficult to predict (Petts, 1979; Gaeuman et al., 2005; Hoffmann et al., 2010). However, as channel aggradation or degradation usually induce adverse economic or environmental consequences, clarifying the connections of aggradation or degradation of a river reach 
to variations in water and sediment inputs, and their causes, is necessary for policy analysis and the formulation of strategies for future management of a catchment.

The Inner Mongolia reach of the Yellow River has an alluvial channel. The changes of water discharge and sediment supply in recent years have induced observable channel adjustment, which was manifested by siltation and shrinkage of the river channel, resulting in aggravation of flooding in spring. The driving forces and dynamic mechanisms of channel adjustment processes in the river reach have been investigated by some studies (Liu et al., 2009; Ta et al., 2008; Fan et al., 2012; Xu, 2013). However, these problems have not been analysed quantitatively. The present study tries to reveal the characteristics of decadal trends in sediment erosion and accumulation in the river channel and quantify the contributions of influencing factors thereto.

\section{STUDY AREA}

The upper Yellow River has a drainage area of 0.386 million $\mathrm{km}^{2}$ and a length of $3472 \mathrm{~km}$ (Figure 1). It descends from an elevation of 4830 to $985 \mathrm{~m}$ (Figure 2). In the reach from Longyangxia Dam to Xiaheyan, the river flows mostly in narrow valleys with an average slope of 0.0015. From Xiaheyan to Qingtongxia Dam, the river flows in the Wei-Ning plain and has a slope of 0.00079 . Downstream of the Qingtongxia Dam, the river enters the
Yinchuan Basin with a slope of 0.00025 between Qingtongxia Dam and Shizuishan. From Shizuishan to Dengkou, the river runs within a narrow valley and has a slope of 0.00029 (Figure 2).

The Inner Mongolia reach is the lowest section of the upper Yellow River (Figures 1 and 2). It extends from Dengkou in the west to Tuoketuo in the east, with a total length of $575 \mathrm{~km}$. In this reach, the river flows in the Hetao Basin, which is bounded by Yin Mountain on the north and the Ordos Plateau on the south. The reach from Dengkou to Sanhuhekou has a length of $214 \mathrm{~km}$ and a slope of 0.00014 with a braided pattern and that downstream of Sanhuhekou has a length of $311 \mathrm{~km}$ and a slope of 0.00010 with a transitional pattern from braided to meandering in its upper section and a meandering pattern in its lower section. As a result of long-term aggradation, some segments of the Inner Mongolia reach have formed a perched channel above the floodplains outside of artificial levees.

The runoff of the upper Yellow River comes mainly from the areas upstream of Lanzhou. The mean annual natural runoff at Lanzhou was close to that at Toudaoguai hydrological station $\left(322.6 \times 10^{8} \mathrm{~m}^{3} /\right.$ year at Lanzhou $v s$ $321.6 \times 10^{8} \mathrm{~m}^{3} /$ year at Toudaoguai) in the period from 1919 to 1975 , so there was no net gain of runoff in the reach from Lanzhou to Toudaoguai. Moreover, owing to water abstraction, the measured mean annual runoff decreased by $67.8 \times 10^{8} \mathrm{~m}^{3} / y e a r$ from Lanzhou to .

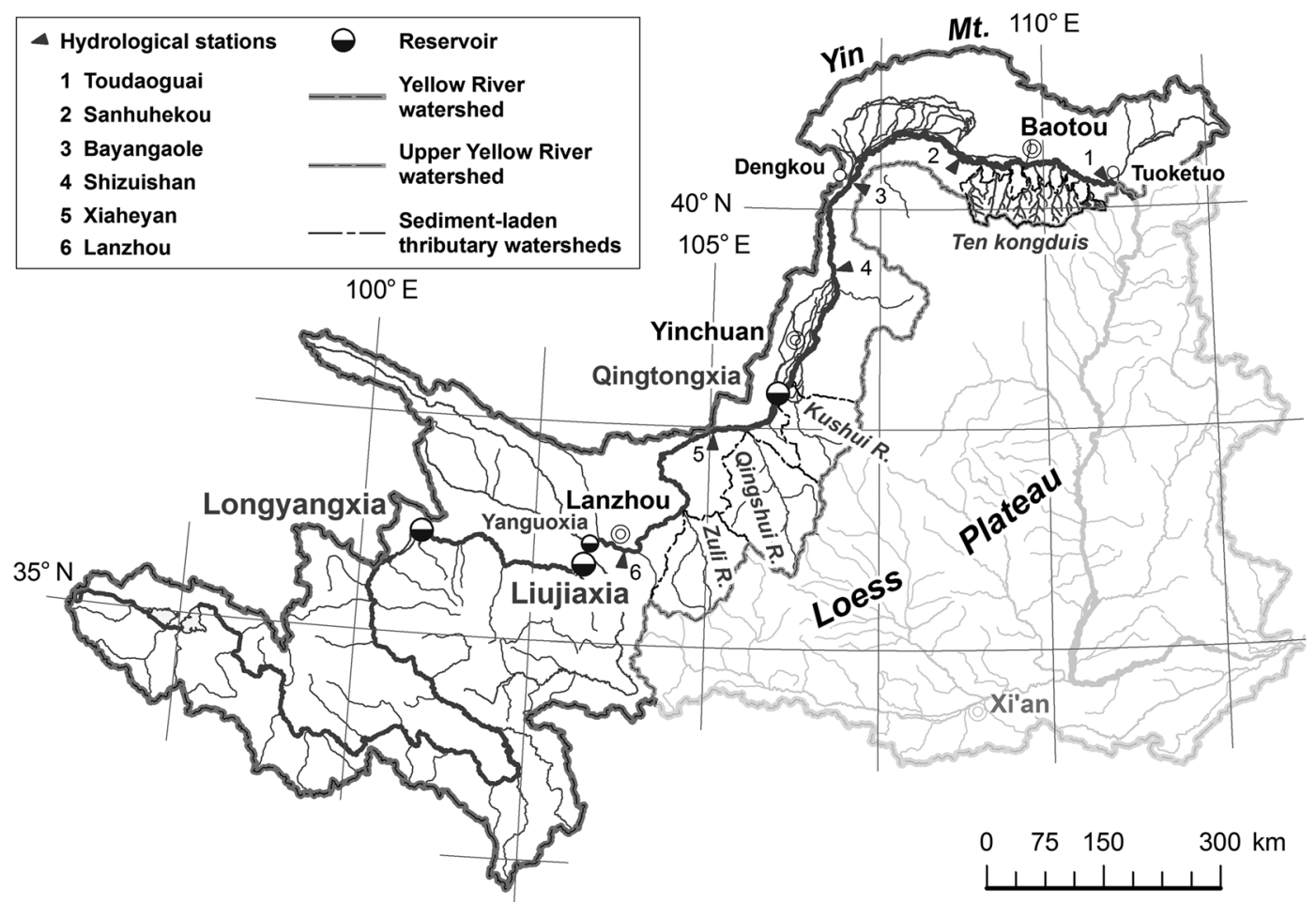

Figure 1. Sketch of the study area 


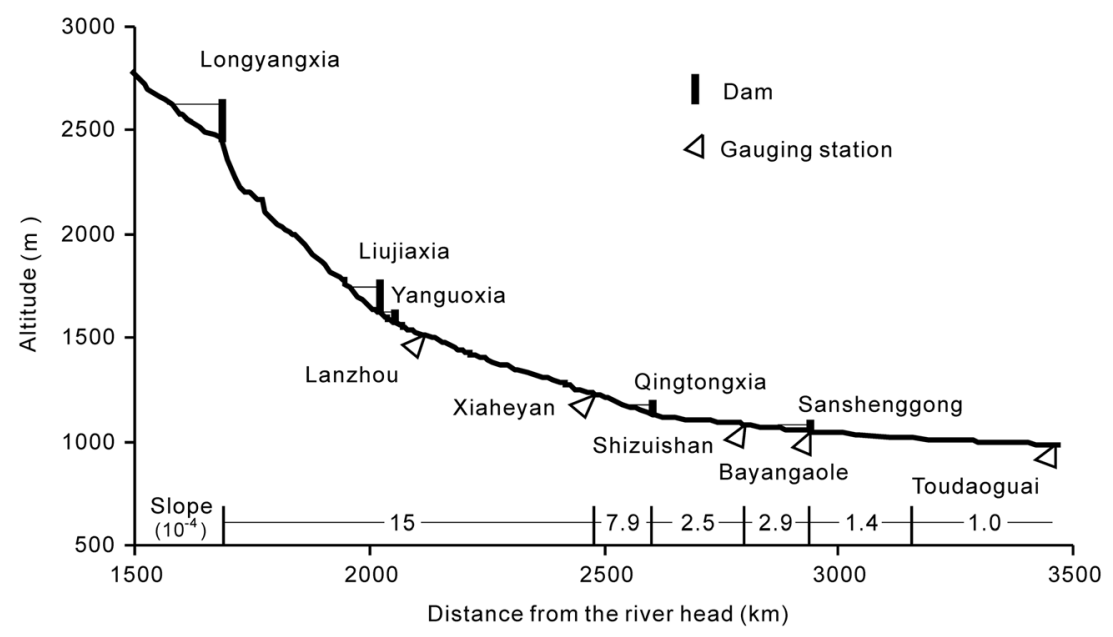

Figure 2. Longitudinal profile of the upper Yellow River

Toudaoguai in the same period. In contrast, there are some tributaries with high sediment load in the reach from Lanzhou to Toudaoguai, so the recorded annual sediment load increased by $51 \%$ on average from Lanzhou to Toudaoguai in the period from 1950 to 2004. These sediment-laden contributors include mainly the Zuli, Qingshui, Kushui rivers, and ten kongduis (ephemeral streams in Mongolian). The former three tributaries drain the northwest Loess Plateau, and the ten kongduis originate from the north of the plateau, which is characterized by prevalent hyper-concentrated flows and thus generates the most sediment in the Yellow River (Xu, 1998; Hassan et al., 2008).

\section{DATA AND METHODOLOGY}

\section{Data sources}

The data collected for this study include the monthly mean water discharge and sediment load recorded at hydrological stations in the reach from Xiaheyan to Toudaoguai and at Lanzhou hydrological station, the annual runoff and sediment load of main tributaries in the reaches between Lanzhou and Toudaoguai, the water storage in main stem reservoirs in flood and dry seasons, the annual volumes of sediment retained behind dams, and the annual volumes of water and sediment diverted to farmlands, along with meteorological records from two stations. The details of each data source are given in Table I.

The ten kongduis are the main local sediment source for the Inner Mongolia reach, but only the sediment load of three kongduis has been gauged over decades. The sediment load of the two kongduis, Maobula and Xiliugou, has been gauged since 1960 and that of the kongdui Hantaichuan since 1980. Thus, the sediment supply from the ten kongduis can only be estimated. All of the ten kongduis flow northward into the Yellow River with their upper reaches in the hilly and gully region with a loess-covered soft Cretaceous sandstone substrate, the middle reaches across the Kobq desert, and the lower reaches through the alluvial plain. In a study on sediment transport in the Sacramento River, California, Singer and Dunne (2001) estimated the sediment discharge from all tributaries draining a common geologic substrate using the suspended sediment records of a single tributary, which was regarded as the 'signature' tributary for that geologic unit. Therefore, the three gauged kongduis can be treated as signature tributaries to estimate the sediment discharge from all the ten kongduis. Here, the estimate is made in four steps: firstly, the yearly mean specific sediment yield of the three gauged kongduis is calculated from records of their sediment load and drainage area. Secondly, the relationship is constructed between the mean sediment yield and the index of precipitation recorded at Baotou and Dongsheng meteorological stations near the ten kongduis. Thirdly, the constructed relationship is used to predict the sediment yield before 1960. Fourthly, the sediment output is approximated to the product of the mean specific sediment yield and total drainage area of the ten kongduis.

\section{Decadal trend identification}

The siltation processes in the Inner Mongolia reach are illustrated by constructing their annual sediment budgets. Using the Pettitt test (Pettitt, 1979), the change-points and decadal trends in the sedimentation sequences are examined. The Pettitt test is a non-parametric test. It uses a version of the Mann-Whitney statistic $U_{t, T}$ to detect change-points in a sequence $x_{1}, x_{2}, \ldots, x_{T}$.

$$
U_{t, T}=U_{t-1 . T}+\sum_{j}^{T} \operatorname{sgn}\left(x_{t}-x_{j}\right), \quad t=2,3, \ldots, T
$$

where $\operatorname{sgn}\left(x_{t}-x_{j}\right)$ equals 1 for $x_{t}-x_{j}>0,0$ for $x_{t}-x_{j}=0$, and -1 for $x_{t}-x_{j}<0$. A potential abrupt change is a point 
Table I. Data sources

\begin{tabular}{|c|c|c|}
\hline Data items & Periods & Sources \\
\hline Monthly mean water discharge and sediment & $1951-2010$ & Collected from Hydrological \\
\hline load in gauging stations including Toudaoguai & & Yearbook of Yellow River issued by Yellow \\
\hline $\begin{array}{l}\text { Sanhuhekou, Bayangaole, Shizuishan, } \\
\text { Xiaheyan, and Lanzhou }\end{array}$ & & River Conservancy Commission \\
\hline $\begin{array}{l}\text { Annual runoff and sediment load of } \\
\text { the Zuli, Qingshui, and Kushui rivers, and } \\
\text { three kongduis }\end{array}$ & 1955-2009 & Zhao et al., 2008 \\
\hline $\begin{array}{l}\text { Water storage in Longyangxia and Liujiaxia } \\
\text { reservoirs in flood and dry seasons }\end{array}$ & 1968-2005 & Zhao et al., 2008 \\
\hline $\begin{array}{l}\text { Annual volumes of irrigation withdrawal and } \\
\text { sediment diverted in the Ningxia and Inner } \\
\text { Mongolia reaches }\end{array}$ & $1952-2005$ & Zhao et al., 2008 \\
\hline $\begin{array}{l}\text { Annual volumes of sediment detained behind } \\
\text { Yanguoxia, Qingtongxia, Liujiaxia, } \\
\text { Longyangxia dams }\end{array}$ & 1961-2005 & Zhao et al., 2008 \\
\hline Meteorological records at Dongsheng and & 1950-2009 & Downloaded from China \\
\hline Baotou meteorological stations & & Meteorological Data Sharing Service System \\
\hline
\end{tabular}

with the maximum absolute values of $U_{t, T}$, expressed as $K_{T}$, and its significance level is estimated by the significance probability $p$, which approximates to:

$$
p \cong 2 \exp \left(-\frac{6 K_{T}^{2}}{T^{3}+T^{2}}\right)
$$

\section{Water-sediment relationship}

The relation between sediment load and water discharge is established for evaluating the contributions of main factors to changes in sediment deposition. According to the commonly used sediment rating curve (Campbell and Bauder, 1940; Asselman, 1999; Syvitski et al., 2000), the water discharge and sediment load can be related by a power function,

$$
Q_{\mathrm{s}}=a Q^{b}
$$

where $Q_{\mathrm{s}}$ is the sediment load, $Q$ is the water discharge, and $a$ and $b$ are fitted parameters. In a study of sediment transport in the lower Yellow River, which is characterized by a high sediment concentration, Qian et al. (1981) found that the bed-material load in a river with a high sediment concentration is related not only to the water discharge but also to the total sediment concentration of incoming water. They attributed the effects of the sediment concentration of incoming water in a highly sediment-laden river to the wide range of sediment concentrations that alter the physical properties of flows and to the intensive erosion and siltation that result in considerable adjustments to the channel geometry, bed material size, and roughness coefficient. The relation of bed-material load with sediment concentration of incoming water was also found to be applicable for evaluating the total suspended sediment load (Zhao et al.,
1998). Also, Wu et al. (2008) argued that it is not necessary to separate the wash load from the bed-material load for computing sediment transport in the Yellow River, and a sediment transport formula for the bed-material load is applicable to the total load. The form of the relations is,

$$
Q_{\mathrm{s}}=a Q^{b} C_{u p}^{c}
$$

where $a, b$, and $c$ are fitted parameters, $Q_{\mathrm{s}}$ and $Q$ are the sediment load and water discharge at a station, $C_{u p}$ is the sediment concentration of the incoming water, which is the ratio of net sediment input to net water input. The net sediment/water inputs are the differences in sediment/water entering the reach under discussion and sediment/water outputs including those retained behind dams and carried away by water diversion in the reach. Equations (3) and (4) are black-box models. There are no definite limits to the length of a river reach or time scale when applying Equations (3) and (4). For a river reach, the sediment transport formula with a form of Equation (3) or (4) are constructed through stepwise regression, and their autocorrelation, collinearity, and heteroscedasticity are diagnosed and corrected using IBM SPSS Statistics.

\section{Attribution}

The contribution to the change in sediment deposition of any factor that alters the water discharge and/or sediment load can be evaluated through Equation (3) or (4). If only one factor induces a change in $Q$ and/or $C_{u p}$, the contribution of that factor to the change in sediment load or sediment deposition is $100 \%$, and the volume of siltation/erosion caused by the factor is simply the difference in $Q_{\mathrm{s}}$ calculated through Equation (3) or (4) with the changed and unchanged values of $Q$ and/or $C_{u p}$. 
When two or more factors modify $Q$ and $C_{u p}$, the volume of siltation/erosion resulting from a factor is estimated by a three-step process: firstly, the volume of siltation/erosion caused by the $i$ th factor $\left(V_{i}\right)$ is evaluated by the difference between the volume of siltation/erosion corresponding to the existing water and sediment inputs and that related with the water and sediment inputs unaltered by the $i$ th factor,

$$
\begin{aligned}
V_{i}= & \left(S-a Q^{b} C_{u p}^{\mathrm{c}}\right) \\
& -\left(S+\Delta S_{i}-a\left(Q+\Delta Q_{i}\right)^{b}\left(C_{u p}+\Delta C_{u p i}\right)^{\mathrm{c}}\right)
\end{aligned}
$$

where $\Delta Q_{i}$ and $\Delta C_{u p i}$ are the changes in water discharge and sediment concentration caused by the $i$ th factor, respectively, $S$ is the existing total sediment input, $\Delta S_{i}$ is the change in sediment input induced by the $i$ th factor, and the others are same as mentioned earlier. The first part (within the first set of brackets) is the volume of siltation associated with the existing water and sediment inputs, and the remaining part is that with the water and sediment inputs unaltered by the $i$ th factor. Secondly, the total volume associated with all factors is evaluated by the difference between the volume of siltation/erosion related with the existing water and sediment inputs and that with the water and sediment inputs unaltered by all factors,

$$
\begin{aligned}
V_{t}= & \left(S-a Q^{b} C_{u p}{ }^{\mathrm{c}}\right) \\
& -\left(\mathrm{S}+\sum \Delta S_{i}-a\left(Q+\sum \Delta Q_{i}\right)^{b}\left(C_{u p}+\sum \Delta C_{u p i}\right)^{\mathrm{c}}\right)
\end{aligned}
$$

Thirdly, the difference between the sum of siltation/erosion volumes owing to individual factors and the total volume derived in the second step is distributed to the volume of siltation/erosion associated with a factor according to the ratio of absolute volume of siltation/erosion induced by the factor derived in the first step to the sum of the absolute volumes,

$$
V_{i r}=V_{i}+\left(V_{t}-\Sigma V_{i}\right)^{*}\left|V_{i}\right| / \Sigma\left|V_{i}\right|
$$

where $V_{i r}$ is the revised volume of siltation/erosion associated with the $i$ th factor.

\section{MAIN FACTORS ALTERING WATER FLOW AND SEDIMENT LOAD}

The source and tributaries of the upper Yellow River have generated a constantly changing runoff and sediment yield, and sediment retention by reservoirs and water use have affected water and sediment transfer along the main stem in the past decades. The effects of these factors on water and sediment discharge of the river are analysed in the following.

\section{Changes in runoff and sediment load upstream of Lanzhou}

The annual runoff and sediment load recorded at Lanzhou station has changed because of climate change and human activities. With the removal of the effects of the main stem dams on runoff regulation, the annual runoff at Lanzhou can be regarded as the annual natural runoff if anthropogenic impacts on runoff generation in tributaries are neglected. Figure 3a shows the changes in annual natural runoff at Lanzhou. It can be seen that the natural runoff fluctuated obviously from year to year with many high values in 19611989 and had kept mostly at a low level since 1990. At the same time, the annual sediment load, which includes sediment carried down from Lanzhou and retained behind upstream dams, also fluctuated noticeably with a stepwise decline of multiannual means (Figure 3a).

\section{Sediment detainment and water regulation by dams}

In the upper Yellow River, the main stem dams that have noticeable impacts on the water discharge and sediment load of the river include Yanguoxia, Qingtongxia, Liujiaxia, and Longyangxia reservoirs. Yanguoxia Reservoir started to store water after 1961 with a designed capacity of $2.16 \times 10^{8} \mathrm{~m}^{3}$. Up to 1964 , its capacity had reduced by $71 \%$ because of siltation (Zhang, 1999). Qingtongxia Reservoir was finished in 1967. It has a designed capacity of $6.06 \times 10^{8} \mathrm{~m}^{3}$. Sediment accumulation had decreased its capacity by $87 \%$ in the first 5 years (Li, 1998). Liujiaxia Reservoir was put into use after 1968. It has a designed capacity of $57 \times 10^{8} \mathrm{~m}^{3}$. In the first 37 years after 1968 , the dam retained about $16.32 \times 10^{8} \mathrm{~m}^{3}$ of sediment (Guo, 2011). Longyangxia Dam was finished in 1986. It has a designed capacity of $274 \times 10^{8} \mathrm{~m}^{3}$. Until 2005 , the dam only retained $4.3 \times 10^{8} \mathrm{t}$ of sediment. Figure $3 \mathrm{~b}$ shows the annual volumes of sediment retained behind these dams. The annual mean volume of retained sediment was $0.87 \times 10^{8} \mathrm{t} /$ year during the periods 1961-2003. It is comparable with the annual sediment load of $0.93 \times 10^{8} \mathrm{t} /$ year gauged at Bayangaole during 1961-2003. On the other hand, Longyangxia and Liujiaxia dams, with their large capacity, may affect downstream sediment transport by regulating water discharge. As shown in Figure 3c, Liujiaxia Reservoir retained $29 \times 10^{8} \mathrm{~m}^{3}$ of water in flood seasons and released about the same annual volume of water in non-flood seasons on average before 1986. From then, Liujiaxia and Longyangxia dams reduced flow by $50 \times 10^{8} \mathrm{~m}^{3} /$ year in flood seasons, and increased flow by $44 \times 10^{8} \mathrm{~m}^{3} /$ year in non-flood seasons on average. Compared with the mean annual flood season runoff of $177 \times 10^{8} \mathrm{~m}^{3}$ at Bayangaole station in 1951-1961, the reservoirs reduced the runoff in flood seasons considerably. Moreover, Longyangxia Dam also altered the annual runoff because of its large capacity. It had stored about $183 \times 10^{8} \mathrm{~m}^{3}$ up to the year 2006 with an annual mean of $8.7 \times 10^{8} \mathrm{~m}^{3} /$ year. 

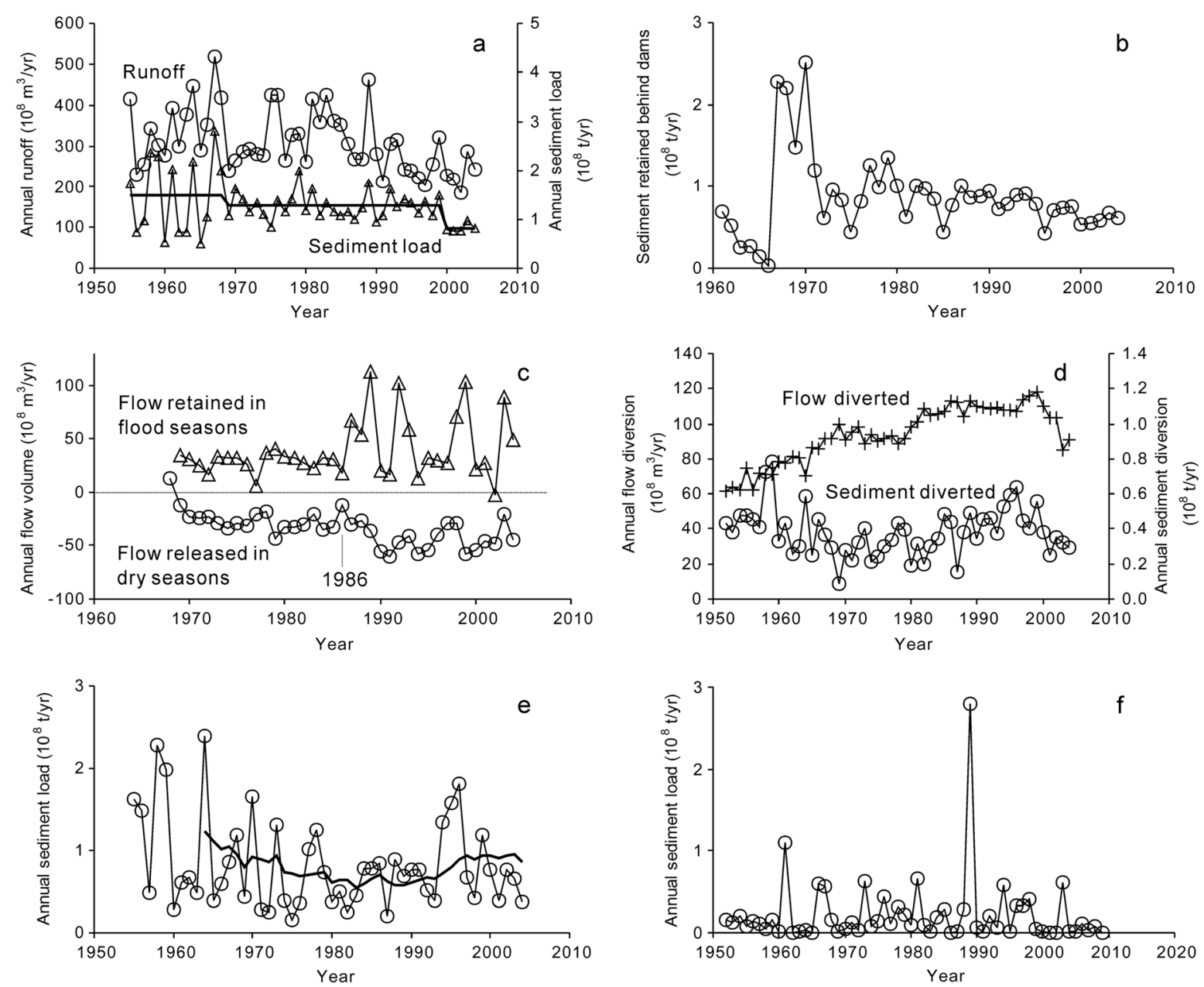

Figure 3. Changes in (a) annual natural runoff and sediment load at Lanzhou with the multiannual means of sediment load shown by a thick line, (b) sediment retention behind main stem dams, (c) flow regulation in flood and dry seasons, (d) water and sediment diversion, (e) total sediment load from three main tributaries with the 10-year moving average presented by a thick line, and (f) annual and cumulative sediment outputs from the ten kongduis

\section{Water and sediment diversion}

Water diversion from the Yellow River mainly occurred in the reach from Xiaheyan to Bayangaole. As shown in Figure 3d, water diversion gradually increased in 1952-1999 and underwent a decline after then. The volume of water diverted in 1955-2003 was about 44\% of the runoff recorded at Toudaoguai station. With water diversion, a large volume of sediment was carried out from the river (Figure 3d). It accounted for 35\% of the sediment load at Toudaoguai station in 1955-2003.

\section{Sediment supply from tributaries}

The sediment load of the three main sediment-laden tributaries (the Zuli, Qingshui, and Kushui rivers) in the reach between Lanzhou and Bayangaole varied from year to year significantly, and its 10-year moving average disclosed a low valley in the period from the middle 1970s to the middle 1990s (Figure 3e). Using the aforementioned method, the sediment load of the ten kongduis downstream of Bayangaole is estimated, and the results are shown in Figure $3 \mathrm{f}$. It is clear that the sediment load of the ten kongduis was highly variable. The seven highest yearly sediment load accounted for over half of the total sediment load in the 58 years from 1952 to 2009 , and the extreme in 1989 was about $21 \%$ of the total load in the 58 years.

\section{EMPIRICAL WATER-SEDIMENT RELATIONSHIPS}

In the Inner Mongolia reach, no channel training practices that had noticeable impacts on sediment transport had been made after 1950. Therefore, it is assumed that sedimentation in the reach has been principally associated with the supply of water and sediment. The impacts of the main factors on sediment erosion and deposition are estimated by considering the volumes of sediment erosion and deposition arising therefrom in both the reaches from Lanzhou to Bayangaole and from Lanzhou to Toudaoguai. The volumes of sediment erosion and deposition are the 
difference between those in the Lanzhou-Toudaoguai and Lanzhou-Bayangaole reaches. Limited by data availability, the calculation of sediment erosion and deposition was made only for the period from 1955 to 2003.

\section{Equations for seasonal sediment load}

Because the sediment transport capacity usually increases with water discharge, the sediment load of total annual flows may be changed when reservoirs reduce their water discharge during high flows in the flood season and increase their low flows in the dry season. As mentioned earlier, starting from 1968, the intra-annual runoff distribution has been affected by Liujiaxia and Longyangxia dams. For estimating the impacts of water regulation by the two dams, the relations between sediment load and mean incoming water and sediment inputs at Bayangaole and Toudaoguai stations are constructed both for the flood and dry seasons in the periods before 1966 when the river was not regulated by the two big reservoirs.

It is found that the annual mean sediment load and water discharge of the flood seasons (June-October) at Toudaoguai station in the period 1951-1966 can be fitted by the relation,

$$
\begin{gathered}
Q_{\mathrm{s}}=0.0998 Q^{1.60} Q_{-1}{ }^{-1.13} Q_{\mathrm{s}-1}{ }^{0.706} \\
\left(n=15 ; r^{2}=0.96 ; p=2.46 \mathrm{E}-10\right)
\end{gathered}
$$

for the dry seasons,

$$
\begin{gathered}
Q_{\mathrm{s}}=0.00000657 Q^{2.36} \\
\left(n=16 ; r^{2}=0.90 ; p=2.08 \mathrm{E}-8\right)
\end{gathered}
$$

for the flood seasons at Bayangaole station in the period 1955-1966,

$$
\begin{gathered}
Q_{\mathrm{s}}=0.00195 Q^{1.04} C_{u p}{ }^{0.59} \\
\left(n=12 ; r^{2}=0.95 ; p=2.04 \mathrm{E}-6\right)
\end{gathered}
$$

for the low flow seasons,

$$
\begin{gathered}
Q_{\mathrm{s}}=0.000674 Q^{1.34} C_{u p}{ }^{0.217} \\
\left(n=12 ; r^{2}=0.92 ; p=9.39 \mathrm{E}-6\right)
\end{gathered}
$$

where $Q_{\mathrm{s}}$ is the mean sediment load in $10^{8} \mathrm{t} / \mathrm{year}$ in the flood or dry season, $Q$ is the mean water discharge in $10^{8} \mathrm{~m}^{3} /$ year in the flood or dry season, $C_{u p}$ is the sediment concentration of the incoming flows in $\mathrm{kg} / \mathrm{m}^{3}, Q_{-1}$ and $Q_{\mathrm{s}-1}$ are the mean water discharge and sediment load, respectively, in the flood season in the last year, and between the brackets, are the number of data samples $(n)$, the determination coefficient $\left(r^{2}\right)$, and the significance level $(p)$.

\section{Equations for yearly mean sediment load}

To estimate the effects on sediment transport of variations of runoff and sediment load from upstream of
Lanzhou, water diversion, sediment retention behind dams, and changes in sediment supply from tributaries, the water-sediment relationships for the reaches between Lanzhou and Bayangaole and between Lanzhou and Toudaoguai stations are constructed using annual runoff and sediment load. In the Lanzhou-Bayangaole reach, the net sediment input is the sediment load at Lanzhou station plus the sediment loads of three main tributaries minus the sediment retained behind dams and carried away by water diversion in this reach. It is the same for the Lanzhou-Toudaoguai reach but includes the sediment loads of ten kongduis. The water input of the Lanzhou-Bayangaole reach can be approximated as the sum of the annual runoff at Bayangaole and the annual increment of water storage in the main stem reservoirs, and that between Lanzhou and Toudaoguai as the sum of the annual runoff at Toudaoguai and the annual increment of water storage in the main stem reservoirs. The sediment load at Bayangaole station includes the sediment load recorded at the station, the sediment diverted with water withdrawal through upstream sluices near the station, and the sediment load increment assuming no reservoir regulation, which equals the volume of the estimated siltation in the Lanzhou-Bayangaole reach induced by reservoir regulation. The sediment load at Toudaoguai station includes the sediment load recorded at the station and the sediment load increment without reservoir regulation. Then, the relation of sediment load at each of the two stations to water discharge and sediment input is established as follows.

For Toudaoguai station,

$$
\begin{gathered}
Q_{\mathrm{s}}=0.00528 Q^{1.99} Q_{-1}{ }^{-1.01} Q_{\mathrm{s}-1}{ }^{0.508} \\
\quad\left(n=46 ; r^{2}=0.90 ; p=6.84 \mathrm{E}-24\right)
\end{gathered}
$$

for Bayangaole station,

$$
\begin{aligned}
Q_{\mathrm{s}}= & 0.00776 Q^{1.56} C_{u p}{ }^{0.446} Q_{-1}{ }^{-0.737} C_{u p-1}{ }^{-0.211} Q_{\mathrm{s}-1}{ }^{0.472} \\
& \left(n=47 ; r^{2}=0.89 ; p=1.04 \mathrm{E}-21\right)
\end{aligned}
$$

where $Q_{\mathrm{s}}$ is the annual mean sediment load in $10^{8} \mathrm{t} / \mathrm{year}$, $Q$ is the annual mean water discharge in $10^{8} \mathrm{~m}^{3} /$ year, $C_{u p}$ is the sediment concentration of the incoming flows in $\mathrm{kg} / \mathrm{m}^{3}$, and $Q_{-1}, Q_{\mathrm{s}-1}$, and $C_{u p-1}$ are the annual mean water discharge, sediment load, and the sediment concentration of the incoming flows, respectively, in the last year. Using Equations (12) and (5) to (7), the volume of siltation/erosion caused by each factor in the LanzhouToudaoguai reach is calculated and that in the LanzhouBayangaole reach is estimated through Equations (13) and (5) to (7). In doing the calculation, the average sediment and water inputs from the drainage areas upstream of Lanzhou and from tributaries in the period 1955-1961 
are treated as the unregulated sediment and water inputs from these sources, and the recorded amounts of water and sediment diversion, sediment retained behind dams, and variations in water storage in reservoirs are the direct changes in water and sediment inputs associated with these factors.

\section{RESULTS}

\section{Channel degradation and aggradation in the Inner Mongolia reach}

The volume of sediment deposition in a river reach is the difference between the inputs and outputs. With the measured annual sediment load at Bayangaole and Toudaoguai stations and the estimated annual sediment output from the ten kongduis, the annual, and cumulative, sediment erosion or deposition volumes in the Inner Mongolia reach are calculated (Figure 4a). It can be seen that the annual series of sedimentation in the channel could be divided into four periods, in which the periods before 1961 and during 1988-2003 were dominated by aggradation; the period 1962-1987 was governed by degradation and the period after 2004 by either slight aggradation or degradation.
To check if the decadal trends in channel sedimentation in the Inner Mongolia reach are statistically significant, the annual siltation sequences are examined by the Pettitt test. As shown in Figure $4 \mathrm{~b}$, there are three change-points in the annual siltation sequence at a significance level of 0.05 . The three change-points divide the annual siltation sequence into four subsequences: 1952-1961, 1962-1987, 1988-2003, and 2004-2009. In other words, the results of change-point testing support the decadal trends in the Inner Mongolia as identified above.

\section{Quantification of contributions of main factors to sedimentation}

By comparing the measured sediment loads at Bayangaole and Toudaoguai stations with those calculated using Equations (8) to (11) and the runoff allocated before being regulated, the effects of runoff regulation by dams are estimated. The results show that the sediment load in the flood seasons was reduced by $0.35 \times 10^{8} \mathrm{t} / \mathrm{year}$ and that in the dry seasons was increased by $0.18 \times 10^{8} \mathrm{t} /$ year at Toudaoguai station in the period 1968-2003, so the total reduction in sediment load was $0.17 \times 10^{8} \mathrm{t}$ /year owing to water regulation by the dams. At Bayangaole
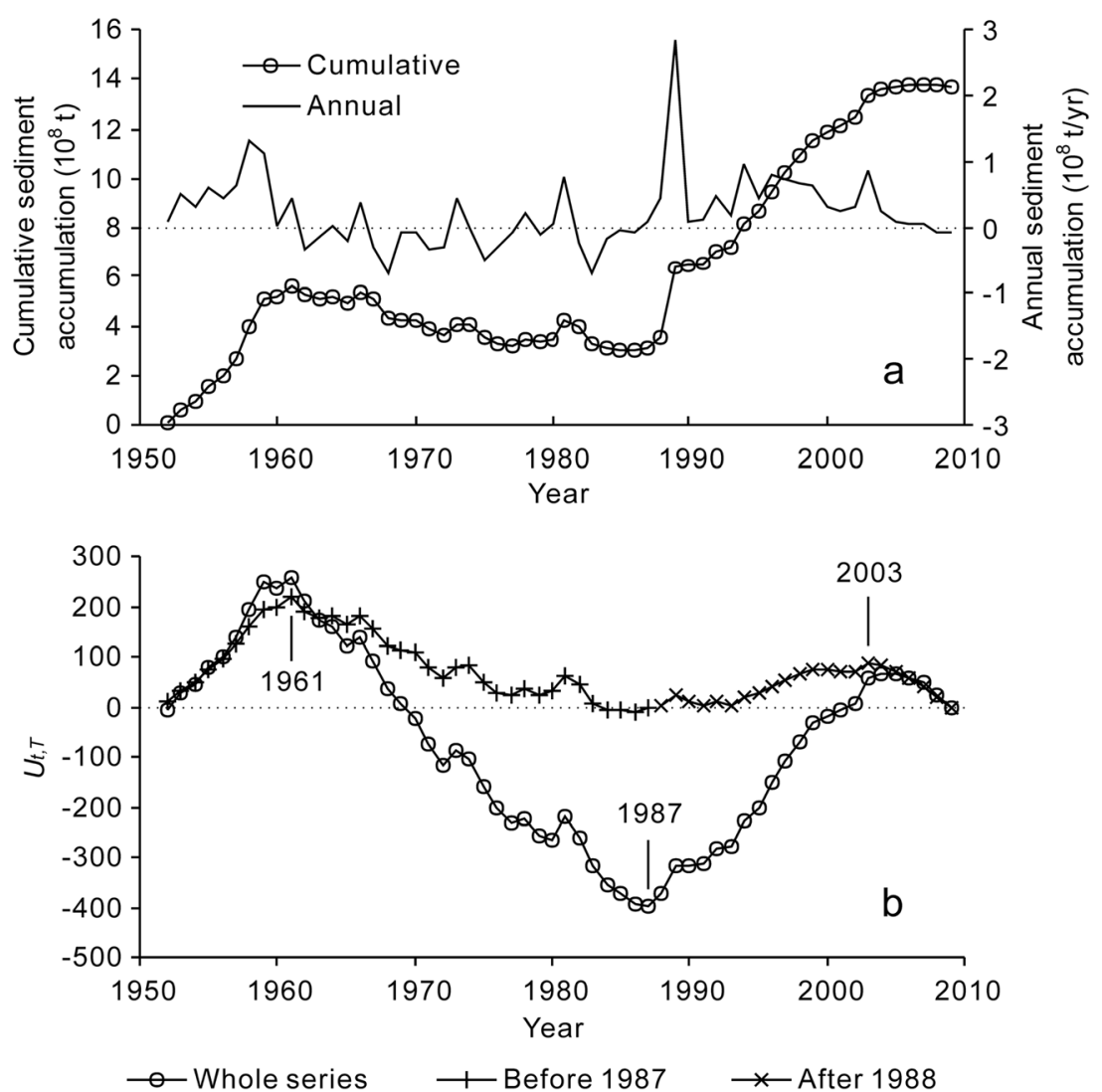

Figure 4. (a) Changes in annual and cumulative sediment accumulation in the Inner Mongolian reach and (b) abrupt changes detected by Pettitt test in the series of annual sediment accumulation values in the Inner Mongolia reach 
station, flow regulation by dams reduced the sediment load by $0.10 \times 10^{8} \mathrm{t} / \mathrm{year}$ in flood seasons and increased the sediment load by a same size annually in dry seasons. Thus, the volume of siltation associated with water regulation by dams was about $0.17 \times 10^{8} \mathrm{t} / \mathrm{year}$ in the reach between Bayangaole and Toudaoguai.

The changes in yearly sediment accumulation associated with four factors in the Inner Mongolia reach are estimated using Equations (12), (13), and (5) to (7), and the results are shown in Figure 5. It is clear that water and sediment diversion had been the principal factors inducing channel aggradation over the period 1955-2003, while other factors also played an important role in the changes in sediment erosion and deposition over time (Figures 5a-d). The volume of annual mean sediment accumulation caused by water and sediment diversion was $0.64 \times 10^{8} \mathrm{t} / \mathrm{year}$ in $1955-2003$. The annual mean volumes of sediment erosion were $0.23 \times 10^{8}$, $0.19 \times 10^{8}$, and $0.21 \times 10^{8} \mathrm{t}$ /year owing to changes in water and sediment inputs from upstream of Lanzhou, sediment supply from tributaries, and sediment retention and water regulation by large dams in the period 1962-2003, respectively. Figure $5 \mathrm{e}$ shows the changes in the total amount of siltation/erosion caused by these four factors. As revealed by the moving average curve, the amount of siltation/erosion caused by the four factors presents the
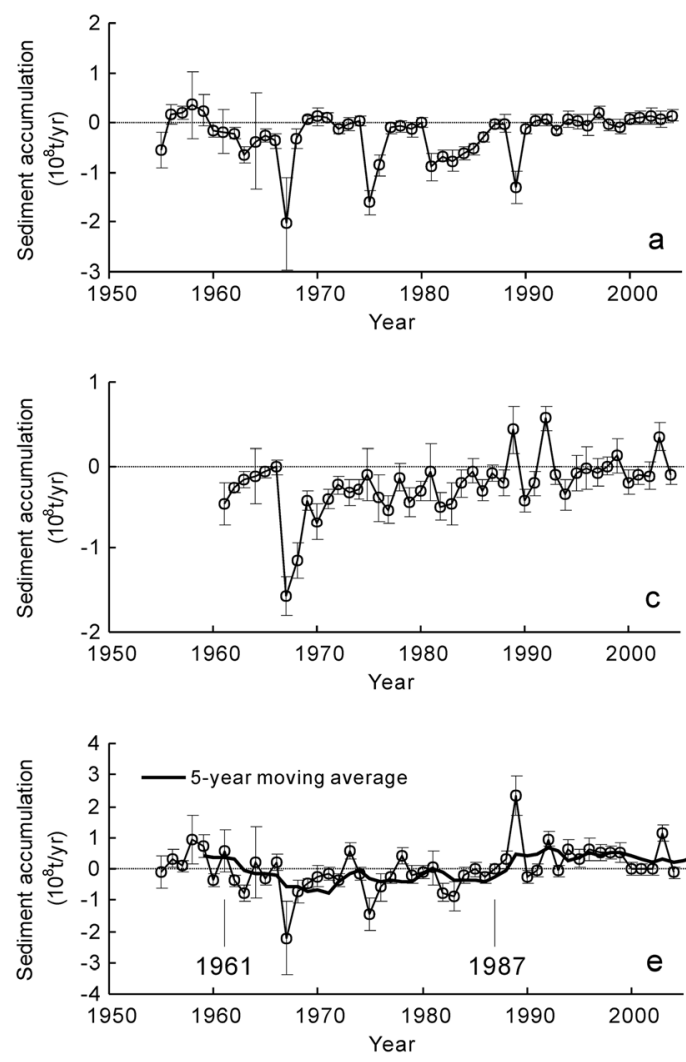

same decadal trends revealed in the sediment accumulation sequence derived from measured annual sediment loads in the Inner Mongolia reach.

\section{DISCUSSION}

\section{Uncertainty analysis}

For examining the uncertainty of the results, a comparison is made between the annual volumes of sediment deposition/erosion derived from the sediment budget of measured sediment inputs and outputs and the sum total of siltation/erosion owing to each factor calculated earlier for the two reaches (Figure 6). It can be seen that there is good agreement between the two. The Nash-Sutcliffe efficiency coefficient is 0.68 for the measured and calculated annual volumes of sediment deposition/erosion in the Lanzhou-Bayangaole reach, and 0.84 for those in the Lanzhou-Toudaoguai reach. In light of the standard errors of predictions by regression relations, the errors are estimated and shown by error bars in Figures 5, 7, and 8b. Unquantifiable errors associated with measured water discharge, sediment load, and sediment retained behind dams are not included.
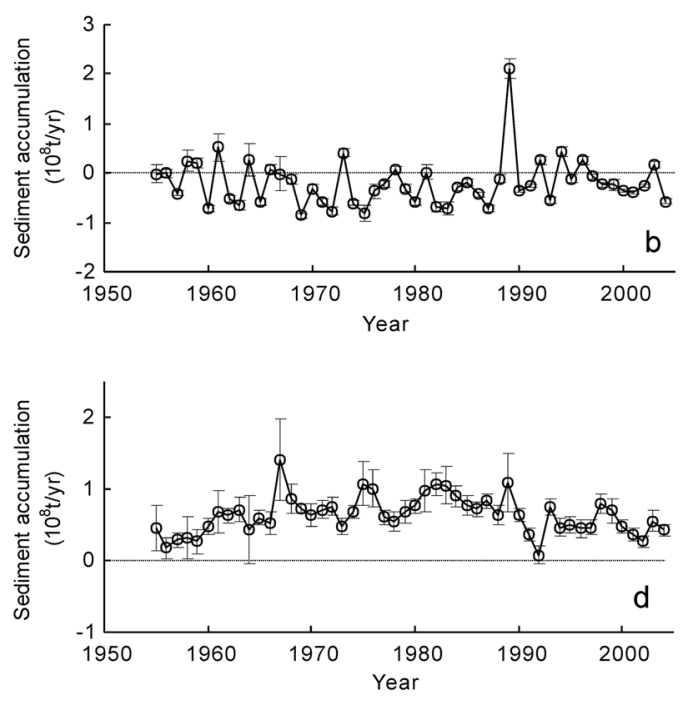

Figure 5. Annual mean sediment deposition/erosion induced by changes in (a) natural runoff and sediment load from the catchment upstream of Lanzhou, (b) total sediment load of the main sediment-laden tributaries, (c) water and sediment regulation by main stem dams, (d) water and sediment diversion, and (e) all of the four factors 

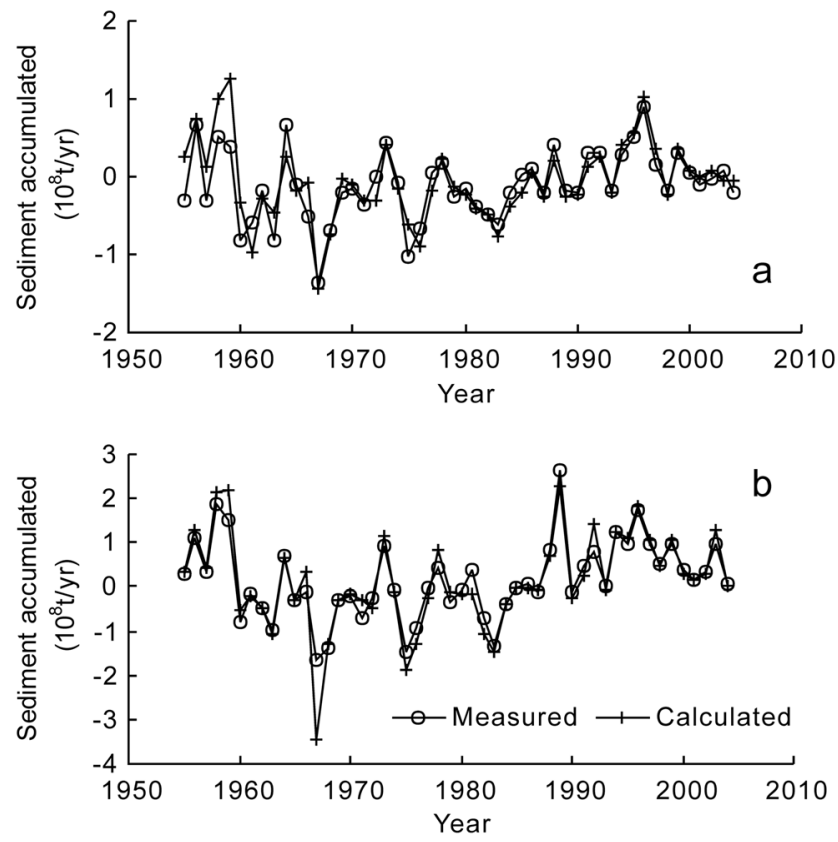

Figure 6. Comparison of calculated and measured annual sediment deposition/erosion in the Lanzhou-Bayangaole reach (a) and in the Lanzhou-Toudaoguai reach (b)

\section{Principal causes for decadal changes of channel aggradation/degradation}

According to the changing trends in channel erosion/ deposition, the processes of channel erosion/deposition in the Bayangaole-Toudaoguai reach, or the Inner Mongolia reach, can be divided into three periods: 1951-1961, 1962-1987, and 1988-2003. In the three periods, the contribution of each of the factors to annual sediment erosion/deposition is shown in Figure 7a, and the changes in annual sediment erosion/deposition owing to each factor in a period against that in the period before are shown in Figure $7 \mathrm{~b}$. Here, the effect of each of the four factors mentioned in the previous section is further separated into that owing to changes in water discharge and that owing to changes in sediment load associated with the factor. It is clear that water diversion had been the principal cause for sediment accumulation in the Inner Mongolia reach (Figure 7a). As to the alteration from channel aggradation before 1961 to channel degradation in the period from 1962 to 1987, the main causes were sediment retention by dams, the increase in runoff, and the decrease in sediment supply from tributaries, which include the main three tributaries between Lanzhou and Bayangaole and the ten kongduis (Figure $7 \mathrm{~b}$ ). The relative reduction of sediment load at Lanzhou also played a certain role in channel erosion during 1962-1987. In contrast, the increase in water diversion, water regulation by reservoirs, and decrease in sediment diversion attenuated the amount of erosion during the same period. In the transition from
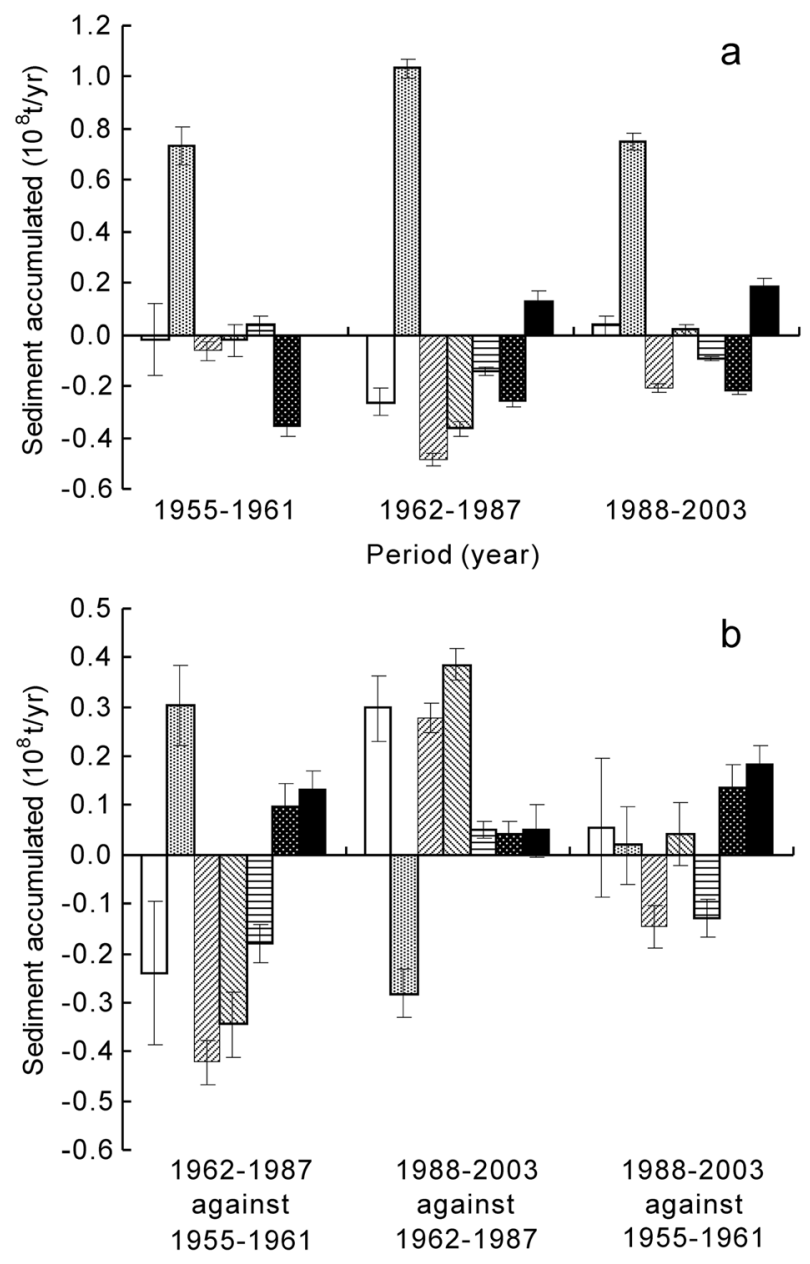

\begin{tabular}{|c|c|}
\hline $\begin{array}{l}\square \text { Natural runoff variation } \\
\text { 闑Water diversion }\end{array}$ & $\begin{array}{r}\text { Sediment inputs from } \\
\text { upstream of Lanzhou }\end{array}$ \\
\hline Sediment detainment by dams & \\
\hline $\begin{array}{l}\text { Sediment inputs from } \\
\text { tributaries }\end{array}$ & $\begin{array}{l}\text { Water regulation by } \\
\text { dams }\end{array}$ \\
\hline
\end{tabular}

Figure 7. (a) Annual mean contributions of each of seven factors to sediment deposition/erosion in three periods and (b) the difference of annual mean sediment erosion/deposition caused by each factor between different periods

erosion before 1987, to deposition thereafter, the main causes were the natural runoff reduction, the increase in sediment supply from tributaries, and the reduction in annual sediment retention behind dams (Figure 7b). On the other hand, the amount of siltation induced by water diversion was lower than that in the previous period. For the increase of sediment accumulation in 1955-1961 to that in 1988-2003, the three main causes are water regulation by the two large reservoirs, natural runoff changes, and the decreased sediment diversion. The increase of water diversion and the rise of sediment inputs from tributaries also played a certain role. In contrast, the sediment retention behind the dams and reduction of sediment supply from the drainage areas upstream of Lanzhou alleviated some of the siltation. 

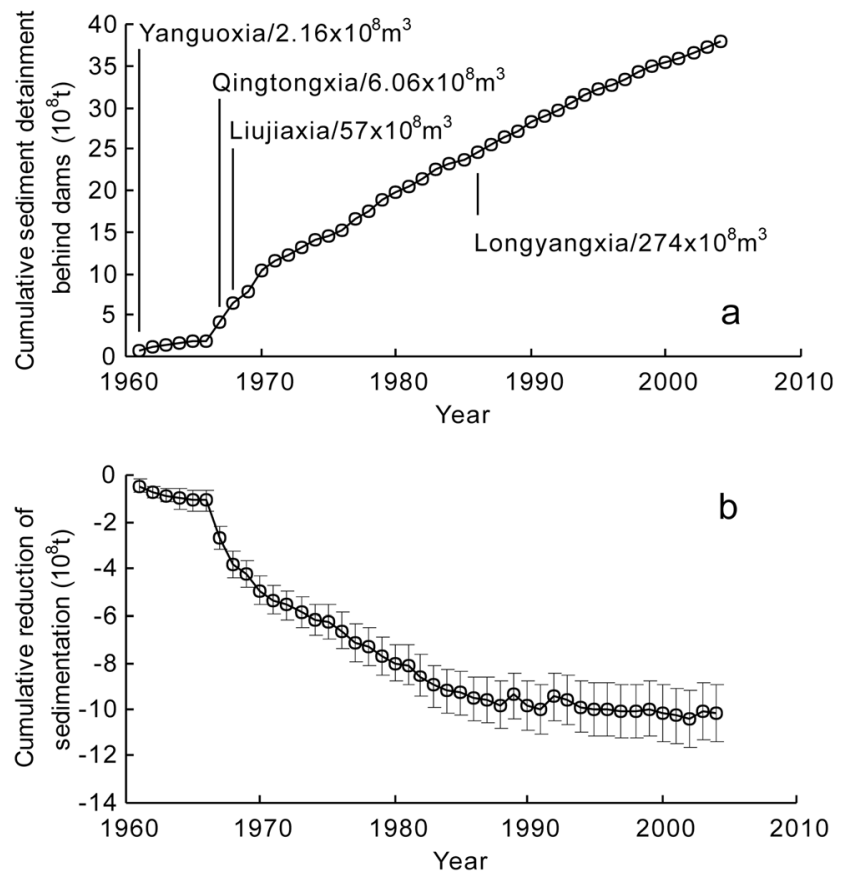

Figure 8. (a) Cumulative sediment retention behind four main stem dams with the completion time of the dams being indicated by the vertical lines and their capacity being noted after the slashes, and (b) cumulative reduction of siltation in the Inner Mongolia reach caused by the four dams

As revealed by previous studies, the sediment transport, or load, in some rivers has been altered noticeably by climate change and/or human activities (Naik and Jay, 2011; Slater and Singer, 2013). The case in the present study shows that both anthropogenic interferences and climate change had also induced considerable variations of sedimentation in the Inner Mongolia reach. Through quantifying the effects of different factors, it is found that their roles in the changes of channel aggradation/degradation, in the reach studied, varied with time. The integrated impacts of influencing factors on water discharge and sediment load were large enough to cause transitions between decadal aggradation and degradation in this naturally aggrading river reach.

\section{Effects of dams on channel aggradation/degradation}

Whether the river channel downstream of a dam aggrades or degrades depends on the contrast between the pre-dam and post-dam water discharge, sediment load, channel slope, and sediment calibre (Schmidt and Wilcock, 2008). Thus, when the reduced sediment transport capacity by water regulation is higher than the sediment load flushing down the dams, a sediment deficit arises, leading to downstream channel degradation. Channel erosion downstream of dams has been widely reported (Petts, 1979; Williams and Wolman, 1984; Xu, 1990; Schmidt and Wilcock, 2008). This study shows that the reduced siltation associated with sediment retention behind upstream dams surpassed the siltation enhanced by flow regulation by dams, alleviating the rate of siltation in the Inner Mongolia reach of the Yellow River. In the period from 1961 to 2003, siltation was reduced by $0.45 \times 10^{8} \mathrm{t} / \mathrm{year}$ in the LanzhouBayangaole reach, and by $0.23 \times 10^{8} \mathrm{t} / \mathrm{year}$ in the Inner Mongolia reach because of the construction of Yanguoxia, Qingtongxia, Liujiaxia, and Longyangxia reservoirs. Sediment retention behind dams played an important role in channel degradation in this aggradation-dominated river reach for over two decades from 1962 to 1987 . The amounts of siltation reduction in the two reaches were $0.41 \times 10^{8}$ and $0.029 \times 10^{8} \mathrm{t} /$ year, respectively, even in the period from 1988 to 2003 when channel aggradation dominated the two reaches. This means that these dams were not the cause of the intensive channel aggradation in the Inner Mongolia reach in the period from 1988 to 2003. Nevertheless, the effects of these dams on downstream siltation alleviation through sediment retention would eventually end. As shown in Figure 8, the siltation reduction associated with the closure of Yanguoxia and Qingtongxia dams ceased in a few years as these two dams have a lower capacity. With a larger capacity, Liujiaxia Reservoir can retain a large volume of sediment, and it may last for a long time before the dam is no longer favourable to downstream siltation alleviation with the decline of its sediment retention efficiency. Yet, after 1986 when Longyangxia Reservoir was put into use, the effects of water regulation were enhanced but the annual total sediment retention behind the main dams was not increased proportionally (Figures $3 \mathrm{c}$ and $8 \mathrm{a}$ ). As a result, downstream siltation owing to water regulation had overtaken the downstream erosion associated with sediment retention behind dams in the Inner Mongolia reach in the last decade of the last century (Figures $5 \mathrm{c}$ and $8 \mathrm{~b}$ ). In other words, it seems that the upper Yellow River was undergoing a changeover from alleviating to aggravating siltation by dams in the downstream reaches owing to the conversion of dominance from sediment regulation to water regulation.

\section{CONCLUSIONS}

Changes in the amounts of sediment erosion/deposition in the Inner Mongolia reach display a transition from aggradation to degradation around the year 1961 and a reversal to aggradation in the year 1987. The decadal trends in sediment erosion/deposition are related with the changes in water and sediment inputs owing to climate change and human activities mainly including water diversion and reservoir construction. Water diversion was a significant factor for the heavy sediment accumulation in the Inner Mongolia reach. Other factors also played an important role in the changes in decadal trends of siltation in 1955-2003. For channel degradation in the period 1962 to 1987 , the main causes included, in the order of decreasing effect: sediment retention behind dams, the 
decrease of sediment supply from the tributaries in the Lanzhou-Toudaoguai reach, the increase of natural runoff, and the decrease of sediment input from the drainage areas upstream of Lanzhou. In this period, the growth of water diversion, water regulation by reservoirs, and the decrease of sediment diversion played the opposite role in channel degradation. The reduction of natural runoff, the relative increment of sediment supply from the tributaries downstream of Lanzhou, and the decrease of sediment retention behind dams were the principal causes of the recurrence of channel aggradation after 1988, while the changes in the effects of water diversion were not favourable to the transition. Large dams built on the main stem of the upper Yellow River had not only enhanced sediment erosion in the Inner Mongolia reach in the period 1962-1987 but also mitigated the intensity of siltation in the reach in the period 1988-2003, yet their role in siltation alleviation attenuated gradually.

\section{ACKNOWLEDGEMENTS}

This study was financially supported by the National Major Basic Research Program of China (grant no. 2011CB403305) and the National Natural Science Foundation of China (grant no. 41371036). The author is thankful to two anonymous reviewers for critical and constructive review comments and suggestions. Thanks also to the Yellow River Water Conservancy Commission and China Meteorological Administration for the permission to access the hydrological and meteorological data.

\section{REFERENCES}

Arnell NW. 1999. Climate change and global water resources. Global Environmental Change 9(1): S31-S49.

Asselman NEM. 1999. Suspended sediment dynamics in a large drainage basin: the river Rhine. Hydrological Processes 13: 1437-1450.

Bichet V, Campy M, Buoncristiani JF, Digiovanni C, Meybeck M, Richard H. 1999. Variations in sediment yield from the Upper Doubs River carbonate watershed (Jura, France) since the late-glacial period. Quaternary Research 51: 267-279.

Brandt SA. 2000. Classification of geomorphological effects downstream of dams. Catena 40: 375-401.

Campbell FB, Bauder HA. 1940. A rating-curve method for determining silt-discharge of streams. EOS. Transactions of the American Geophysical Union 21: 603-607.

Clark JJ, Wilcock PR. 2000. Effects of land-use change on channel morphology in northeastern Puerto Rico. Geological Society of America Bulletin 112: 1763-1777.

Clift PD. 2006. Controls on the erosion of Cenozoic Asia and the flux of clastic sediment to the ocean. Earth and Planetary Science Letters 241: 571-580.

Fan XL, Shi CX, Zhou YY, Shao WW. 2012. Sediment rating curves in the Ningxia-Inner Mongolia reaches of the upper Yellow River and their implications. Quaternary International 282: 152-162.

Gaeuman D, Schmidt JC, Wilcock PR. 2005. Complex channel responses to changes in stream flow and sediment supply on the lower Duchesne River, Utah. Geomorphology 64: 185-206.
Guo JL. 2011. Analysis on morphology of sedimentation of Liujiaxia Reservoir. Yellow River 33(1): 20-21. (in Chinese with an English abstract) Hassan MA, Church M, Xu J, Yan Y. 2008. Spatial and temporal variation of sediment yield in the landscape: example of Huanghe (Yellow River), GeophysicalResearchLetters 35,L06401, DOI: 10.1029/2008GL033428.

Hay WW. 1994. Pleistocene-Holocene fluxes are not the Earth's norm. In Material Fluxes on the Surface of the Earth, Board on Earth Sciences and Resources, Commission on Geosciences, Environment, and Resources, National Research Council (eds.). National Academy Press: Washington, D.C.; 15-27.

Hoffmann T, Thorndycraft VR, Brown AG. 2010. Human impact on fluvial regimes and sediment flux during the Holocene: review and future research agenda. Global and Planetary Change 72(3): 87-98.

Knox JC. 1993. Large increases in flood magnitude in response to modest changes in climate. Nature 361: 430-432.

Korhonen J, Kuusisto E. 2010. Long term changes in the discharge regime in Finland. Hydrology Research 41: 253-268.

Kosmas C, Danalatos N, Cammeraat LH. 1997. The effect of land use on runoff and soil erosion rates under Mediterranean conditions. Catena 29: $45-59$.

Lane EW. 1955. The importance of fluvial geomorphology in hydraulic engineering. American Society of Civil Engineers Proceedings 81: 1-17.

Li TQ. 1998. Sediment accumulation in Qingtongxia Reservoir. Large Dam \& Safety (4): 21-27. (in Chinese)

Liu XY, Hou SZ, Chang WH. 2009. Cause of main channel shrinkage occurred to the Inner Mongolian Mongolia reaches of Yellow River. Journal of Hydraulic Engineering 40: 1048-1054. (in Chinese with an English abstract)

Mackin JH. 1948. Concept of the graded river. Geological Society of America Bulletin 59: 463-512.

Macklin MG, Jones AF, Lewin J. 2010. River response to rapid Holocene environmental change: evidence and explanation in British catchments. Quaternary Science Reviews 29: 1555-1576.

Meybeck M. 2003. Global analysis of river systems: from Earth system controls to Anthropocene syndromes. Philosophical Transactions of the Royal Society, Biological Sciences 358: 1935-1955.

Naik PK, Jay DA. 2011. Distinguishing human and climate influences on the Columbia River: changes in mean flow and sediment transport. Journal of Hydrology 404: 259-277.

Owens P, Slaymaker O. 1994. Post-glacial temporal variability of sediment accumulation in a small alpine lake [C]. In Variability in Stream Erosion and Sediment Transport, Olive LJ, Loughran RJ, Kesby JA (eds.). IAHS Publ. 224: 187-195.

Pettitt AN. 1979. A non-parametric approach to the change -point problem. Applied Statistics 28(2): 126-135.

Petts GE, Gurnell AM. 2005. Dams and geomorphology: research progress and future directions. Geomorphology 71: 27-47.

Petts GE. 1979. Complex response of river channel morphology subsequent to reservoir construction. Progress in Physical Geography 3: $329-362$.

Qian N (Chien N), Zhang R, Li JF, Hu WD. 1981. A preliminary study on the mechanism of self regulation of sediment transport capacity in the lower Yellow River. Acta Geographica Sinica 36: 143-156. (in Chinese with an English abstract)

Schmidt JC, Wilcock PR. 2008. Metrics for assessing the downstream effects of dams. Water Resources Research 44(4): W04404. DOI:10.1029/2006WR005092.

Shi CX, Zhang L, Xu JQ, Guo LP. 2010. Sediment load and storage in the lower Yellow River during the late Holocene. Geografiska Annaler: Series A, Physical Geography 92: 297-309.

Shi CX, Zhou YY, Fan XL, Shao WW. 2013. A study on the annual runoff change and its relationship with water and soil conservation practices and climate change in the middle Yellow River basin. Catena 100: $31-41$.

Schumm SA, Lichty RW. 1965. Time, space, and causality in geomorphology. American Journal of Science 263: 110-119.

Singer MB. 2007. The influence of major dams on hydrology through the drainage network of the Sacramento Valley, California. River Research Applications 23(1): 55-72.

Singer MB. 2010. Transient response in longitudinal grain size to reduced gravel supply in a large river. Geophysical Research Letters 37(18), L18403, DOI: 12010g1044381/12010g1044381. 
Singer MB, Dunne T. 2001. Identifying eroding and depositional reaches of valley by analysis of suspended sediment transport in the Sacramento River, California. Water Resources Research 37(12): 3371-3381.

Singer MB, Aalto R, James LA, Kilham NE, Higson JL, Ghoshal S. 2013. Enduring legacy of a toxic fan via episodic redistribution of California gold mining debris. Proceedings of the National Academy of Sciences 110(46): 18436-18441.

Slater LJ, Singer MB. 2013. Imprint of climate and climate change in alluvial riverbeds: continental United States, 1950-2011. Geology 41: 595-598.

Syvitski JPM, Kettner A. 2011. Sediment flux and the Anthropocene. Philosophical Transactions of the Royal Society 369: 957-975.

Syvitski JPM, Milliman JD. 2007. Geology, geography, and humans battle for dominance over the delivery of fluvial sediment to the coastal ocean. Journal of Geology 115(1): 1-19.

Syvitski JPM, Morehead MD, Bahr DB, Mulder T. 2000. Estimating fluvial sediment transport: the rating parameters. Water Resources Research 36: 2747-2760.

Syvitski JPM, Vörösmarty CJ, Kettner AJ, Green P. 2005. Impact of humans on the flux of terrestrial sediment to the global coastal ocean. Science 308: 376-380.

Ta WQ, Xiao HL, Dong ZB. 2008. Long-term morphodynamic changes of a desert reach of the Yellow River following upstream large reservoirs' operation. Geomorphology 97: 249-259.

Tornqvist TE. 2007. Responses to rapid environmental change. In Encyclopedia of Quaternary Science, Elias SA (ed.). Elsevier: Amsterdam; 686-694.

Trimble SW. 1981. Changes in sediment storage in the Coon Creek Basin, Driftless Area, Wisconsin, 1853 to 1975 . Science 214: 181-183.

Tucker GE, Slingerland R. 1997. Drainage basin responses to climate change. Water Resources Research 33: 2031-2047.

Vörösmarty CJ, Meybeck M, Fekete B, Sharma K, Green P, Syvitski JPM. 2003. Anthropogenic sediment retention: Major global impact from registered river impoundments. Global and Planetary Change 39: $169-190$.

Walling DE. 2006. Human impact on land-ocean sediment transfer by the world's rivers. Geomorphology 79: 192-216.

Walling DE. 2009. The impact of global change on erosion and sediment transport by rivers: current progress and future challenges. Unesco.
Ward PJ, van Balen RT, Verstraeten G, Renssen H, Vandenberghe J. 2009. The impact of land use and climate change on late Holocene and future suspended sediment yield of the Meuse catchment. Geomorphology 103: 389-400.

Wilkinson BH, McElroy BJ. 2007. The impact of humans on continental erosion and sedimentation. Geological Society of America Bulletin 119(1-2): 140-156.

Williams GP, Wolman MG. 1984. Downstream Effects of Dams on Alluvial Rivers. US Government Printing Office: Washington, DC, USA.

Wu B, van Maren DS, Li L. 2008. Predictability of sediment transport in the Yellow River using selected transport formulas. International Journal of Sediment Research 23(4): 283-298.

Xu JX. 1990. An experimental study of complex response in river channel adjustment downstream from a reservoir. Earth Surface Processes \& Landforms 15: 43-53.

Xu JX. 1998. A study of physico-geographical factors for formation of hyperconcentrated flows in the Loess Plateau of China. Geomorphology 24: 245-255.

Xu JX. 2004. A study of anthropogenic seasonal rivers in China. Catena 55: $17-32$.

$\mathrm{Xu}$ JX. 2013. Complex response of channel fill-scour behavior to reservoir construction: an example of the upper Yellow River, China. River Research and Applications 29: 593-607.

Zhang Y 1999. An analysis of measurements of sediment accumulation in Yanguoxia Reservoir. Large Dam \& Safety (1): 14-21. (in Chinese)

Zhang D, Shi CX. 2001. Sedimentary causes and management of two principal environmental problems in the lower Yellow River. Environmental Management 28(6): 749-760.

Zhao YA, Dai MY, Xiong GS, Lu GY, Zeng ML. 2008. Key Techniques of Water and Sediment Regulation and Operation Patterns of Longyangxia and Liujiaxia Reservoirs. Unpublished report, Yellow River Institute of Hydraulic Research, Yellow River Conservancy Commission. (in Chinese)

Zhao YA, Zhou WH, Fei XJ, Hu CH, Shen GQ, Chen JG. 1998. Channel Change of the Lower Yellow River. Yellow River Conservancy Press: Zhengzhou. (in Chinese)

Zolitschka B. 1998. A 14000 year sediment yield record from western Germany based on annually laminated lake sediments. Geomorphology 22: $1-17$. 